\title{
The Impact of Gender and Reading Level on: Student Perception, Academic Practice, and Student Enjoyment
}

\author{
Chris Sclafani ${ }^{1} \&$ Dennis Wickes ${ }^{2}$ \\ ${ }^{1}$ Hofstra University, Hempstead, NY, USA \\ ${ }^{2}$ Dowling College, Oakdale, NY, USA \\ Correspondence: Dennis Wickes, Dowling College, Oakdale, NY, USA. E-mail: dennis.wickes@my.liu.edu; \\ Chris Sclafani, Hofstra University, Hempstead, NY, USA. E-mail: csclafani1@pride.hofstra.edu
}

Received: December 3, 2016

Accepted: January 5, 2017

Online Published: February 6, 2017

doi:10.5539/jel.v6n2p196

URL: http://dx.doi.org/10.5539/jel.v6n2p196

\begin{abstract}
Much research has been conducted on reading levels of elementary school students. Teachers search for learning experiences that lend inclusion to all genders and levels. How does this all lay out for the students? The initial trial of the study looks into the impact and differences of gender and/or reading level on areas such as school enjoyment, self-perception, and academic practice in the lives of 59, fifth grade, suburban students. A subsequent study was done with identical goals in the following school year as well. This newer study (trial two) included 103 students from grades two through five in the same suburban area school. These students were given surveys that allowed scores to be ascertained in the aforementioned areas of concern. Surveys were given out and scored on a Likert-type scale ranging from 1-5 ( $1=$ most negative, $5=$ most positive). The data was entered into SPSS where various tests such as MANOVA, correlations, Levene's, and t-tests were performed. While a great deal of the areas were not initially identified as statistically significant in trial one, the area of gender and its relationship with enjoyment did appear to be significant at the $\mathrm{p}<.05$ level. The larger, more recent trial, found gender's impact on school enjoyment, self-perception, and academic practice time. This study could give educators introspective into the way their students think about school.
\end{abstract}

Keywords: literacy, self-perception, elementary, gender, academic practice

\section{Introduction}

Differences among humans is at the forefront of everyday problems within society. Variance between factors such as race, ethnicity, and gender are ubiquitous throughout the world. Ironically, of the billions of humans that presently roam the earth, we are all incredibly similar. In fact, "the DNA of all human beings living today is $99.9 \%$ alike" (Smithsonian). Remarkably, it is just $0.1 \%$ of our DNA that separates all Homo sapiens from one another and makes us all inevitably unique. Upon coming to the realization that humans are in fact more similar than we are different, it leads to the question; how is it that such a small variance in human DNA can be such a prominent, relevant topic in nearly all trending facets of life? In education, gender and race are constant variables examined in student performance. In job acquisition, these same factors have been such a large issue that affirmative action was instituted to help deter employer discrimination.

Since the start of the second half of the twentieth century, instructors and educational theorists have viewed literacy with a highly analytical lens. It is common to see teachers assign and discuss reading levels as a basic academic achievement measure. Likewise, there is a growing number of educators who view these levels as something that informs a great deal more than simple performance assessment. The latter group elects to see the wider reaching, holistic impact that a student's level of literacy development has upon the many facets of his or her life. When speaking of these apparent differences in perspective, Yetta and Ken Goodman (2003) argue that reading is far too complex to fit into one simple area of academia. "Such fragmentation, although it simplifies research design and the complexity of the phenomena under study, seriously distorts the process, tasks, cue values, interactions and realities" (Goodman \& Goodman, 2003, p. 121). Additionally, with books like Linda Bausch's (2014) Boys Will Be Boys? Bridging the Great Gendered Literacy Divide becoming popular among in the educational community, the awareness of gender differences in relation to key scholarly and personal issues is also a topic for exploration. 
Gender differences among students exist in numerous facets of education. For instance, females generally outperform males in all major content areas throughout grade school. However, they fail to outperform males on tests for achievement and IQ (Duckworth \& Seligman, 2006). Why are girl's performances superior to that of boys throughout elementary and secondary schools, yet boys tend to top the charts in achievement and/IQ oriented tests? Is this disparity in grades a result of student motivation across the board? Could it be better attributed to student enjoyment and perception? Data regarding gender differences related to academic performances needs to be reviewed to try create a more level playing field for all students involved.

While these items might have importance at both national and international levels, it is the local level that is being sampled here. Today's teachers are more aware of their students' reading abilities. Nearly all schools have some method for denoting the reading level of children. Most children know the state test score that they received from their ELA exams, but do they know the gravity of that score? Fountas and Pinnell letter levels are assigned in ascending order to schools utilizing that testing system. Students must read within the letter designation that the assessments show. Additionally, programs like Read 180 and DRA-2 openly reveal the final score that a reader earns at the conclusion of testing. What impact does this have on these students? Is this impact different between boys and girls? Are schools unintentionally favoring or aiding one particular gender over another? The research that follows will help answer these questions, and more specific research questions. This is a two-part study, and when necessary, these parts will be separated to create higher levels of clarity for the reader. When appropriate, a complete overview of the information, encompassing the entire study as a whole, will be provided.

\subsection{Research Questions}

Is there a correlation between gender and school enjoyment, self-perception, and/or academic practice?

Is there a significant main effect of gender, and/or reading level on the areas of school enjoyment, self-perception, and/or academic practice?

Is there a significant difference between genders on reading enjoyment, self-perception, and/or academic practice?

Is there a significant difference between reading levels on reading enjoyment, self-perception, and/or academic practice?

\subsection{Rationale}

As seen in the above section (Research Questions 1.1), this study places its central focal point on students. Teachers, regardless of their educational settings, are likely to encounter students with fixed factors that either mimic or closely resemble those that were chosen for this research. The commonality of these independent variables is clear when one looks into a public-school classroom and sees students of variant reading levels and genders. There is often much talk in public and political forums about what should be taught, and even how it should be taught, yet this leaves out who is being taught. It is sometimes beneficial to use factors outside of those curriculum-based ideas, and delivery methods. Educators could benefit from the usage of traits that exist in basically any public-school classroom, and then view how these might impact young learners. There is sometimes a need to step outside of the world of grades, instruction manuals, and standards, in order to look more deeply into factors that appear rather basic in nature, but have rather far-reaching instructional implications.

\section{Literature Review}

There is extensive data from studies that have looked into the role of reading level and/or gender on students' affect towards school, themselves, and academic practice. Some of this work included factors such as reading level and gender, among many additional variables being tested. Others were more singular in their approach. The time periods for the works cited in this section ranges widely to allow for the inclusion of work from experts in the reading field, and as well as educational institutions. All articles are peer-reviewed and were located through academic search engines.

\subsection{The Role of Self-Perception}

In a majority of research related to reading level and self-confidence or belief, the high and low ends of the spectrum seem to be most common. In a study of classrooms and affective factors, Coombs and Edwards (2013) stated "Students who struggle with reading often have a weak sense of self-efficacy (personal belief in their own abilities) and resist taking the kinds of risks required to practice and develop reading skills" (p. 24). The author has not only seen connections with lower reading levels and lower self-confidence, but also the idea that lower level readers are less likely to practice reading than others is brought to the forefront. "From our experiences, we found beginning and struggling readers may lack confidence that they will be able to read texts they perceive as created for more capable readers" (Coombs \& Edwards, 2013, p. 24). Thus, if there is a general disillusionment about 
creating more challenging and beneficial learning experiences, it can be due, in part, to the reader's own thoughts about his or her abilities. "Students who participated in active comprehension had more to say about the experience, and what they had to say was positive" (Yopp \& Dreher, 1994, p. 298). "Active comprehenders" are the goal of many reading instructors, as they learn while they are reading, as opposed to simply calling out words without adequate factual recall. It appears that these "active comprehenders" are positioning themselves to demonstrate proficiency in the areas of reading and learning. There are concurring viewpoints in the area of writing research. "In addition, students' own self evaluations included self-reflection geared to understanding the affective and motivational self-beliefs that are an essential part of writing" (Pajares, 2003, p. 154). Not unlike the previous research, the links are made between affective factors and the actual process in question. Other studies concur with this evidence, and also delve into the area of writing. Pajares and Johnson (1993) did statistical research on 30 students and found, that "Results indicated support for social cognitive theory and prior findings that report a relationship between self-efficacy and performance. A regression model accounted for $68 \%$ of the variance in writing performance" (p. 1). A common theme conjoining both reading and writing level with attitudes about performance has thereby emerged.

\subsection{The Role of Practice}

As with many things in the field of education, practice is an important part of becoming successful. Santarpia and Voos (2003) worked with scales of reader self-perception and concluded, "That is, how an individual feels about herself or himself as a reader could clearly influence whether reading would be sought or avoided, the amount of effort that would occur during reading, and how persistently comprehension would be pursued" (p. 8). This study supports the notion that reading is not a neutral act that is approached in the same manner by all students. Instead, they purvey the concept that reading could be avoided or performed more frequently, and that this is dependent upon how the readers view themselves within this process. After performing multiple case studies, Schirmer and Schaffer (2010) discussed why a lower reader might not engage in regular practice.

The major reasons appear to involve frustration with a task at which they fail repeatedly, avoidance of poor reading performance in front of peers, desire to be perfect and inability to perform error-free, wish to protect their self-esteem, and learned helplessness or a sense that no matter what they do, it will not improve. The student with a negative attitude towards reading is likely to avoid school-related and recreational reading (p. 19).

Through the observation of a wide range of students, there is an understanding that there are prominent links between the amount of actual reading a student does, and the way they feel about their own reading abilities. Clearly, lower level readers would be the point of reference in the above quote.

\subsection{The Role of Gender}

Some researchers have studied the potential role that gender plays upon young readers and writers. Edward Kifer is among those researchers. Kifer (1973) studied 441 students from grades two through eight, with measures to judge school achievement and self-perception. He hypothesized, "There will be no significant difference between boys and girls in the relationships between successful and unsuccessful school achievement and their perceptions of themselves and their abilities" (p. 15). The results of running the data came out as insignificant at the .05 level. Other studies tend to state that females score higher in certain areas of reading.

In 43 countries, 199,097 fifteen-year-olds completed a reading comprehension test and a questionnaire. We analyzed the data using multi-level regressions of Rasch-estimated test scores to test the associations of gender and context on reading achievement among adolescents. In every country, girls outscored boys. Reading enjoyment mediated $42 \%$ of the gender effect. No other predictor significantly mediated the gender effect (Chiu \& McBride-Chang, 2006, p. 2).

Through the use of regression, there is once again a separation between the genders that emerges in this rather extensive international study. This data is again bolstered by other pertinent research. "We found a statistically significant gender-by-grade interaction for the recreational scale, $\mathrm{F}(3,182)=5.42, \mathrm{P}<.001$. On the recreational scale, girls demonstrated more positive reading attitudes than did boys and maintained these differences at all levels except one" (Kush \& Watkins, 1996, p. 317). The aforementioned statement was written after reviewing the reading attitudes surveys of 190 students over a three-year period. Apparently, girls find higher levels of school enjoyment than boys as well. In a study of 2,200 elementary school students, Gentry, Gable, and Rizza (2002) ran a regression revealing the following data:

Significant contributors to the gender differences were as follows: Grade 3 -enjoyment, $\beta=.19, p<.0001$; Grade 4 -interest, $\beta=.12, p<.05$; Grade 5-enjoyment, $\beta=.18 \mathrm{p}<.01$; Grade 6 - no variables were significant; Grade 7 -enjoyment, $\beta=.17, p<.01$; Grade 8 - enjoyment, $\beta=.23$, $p<.001$. In all of these cases, across grade levels, female 
students consistently perceived their classroom activities to be frequently more enjoyable than did the male students (p. 542).

The repetitive consistency of this study's results are worthy of reflection. There are scores in the above quote that are significant when $\mathrm{p}$ values are set as low as .0001 . Beyond this, there appears to be a very clear pattern to observe, as girls recorded higher scores than their male counterparts, primarily in the area of "enjoyment" across multiple grade levels.

\section{Participants}

\subsection{Trial 1 Participants}

Children from three classes in a suburban elementary school in Suffolk County were selected to take the surveys. All students were fifth graders in the initial study and in these particular classes, all students were the appropriate chronological age for a fifth grader (age ten or eleven). Every student with the exception of two lived in the geographic area denoted for enrollment of the school being studied. The two students who did not live in this vicinity received mini-bus service to and from a nearby homeless shelter. The 59 total students who participated in the survey contained 32 boys and 27 girls. No compensation or special privileges were granted as a result of their completion of the survey. It was observed both personally and by teachers administering the surveys that students generally took them seriously.

Levels for students (1-4) were determined by the Scholastic Reading Inventory, a computer-based adaptive test, Fountas and Pinnell letter levels, program designation, and/or classroom performance grade. These multiple measures allow for a far clearer picture of the student being viewed. Student gender was noted on each individual survey.

\subsection{Trial 2 Participants}

Students in the subsequent trial were also students attending the school used for trial one. The location did not change. Surveys were distributed and completed by students in grades two through five. Out of a total of 103 students, six students in this trial did not reside within the borders of the actual district itself, but were allowed to attend this school using a bus service that picked them up from nearby homeless shelters. These students were also not given any type of remuneration in exchange for the completion of surveys. Everything completed by participants in this study was done on a strictly voluntary basis. Students were rated for "level" by the same measures utilized in trial one.

\section{Measures and Procedure}

A survey was created that positioned statements and questions in a format bearing great similarity to a Likert scale. The questions were aimed to add to the students' score out of a possible five points (indicating the highest level of positivity in each case). One was the lowest level of "approval" or "agreement" and five was always the highest. All student enjoyment scores were based upon three questions/statements totaling up to a highest possible score of 15 and a lowest possible score of 3 . All self-perception scores were based upon information from five questions and/or statements. The highest total here was 25 and the lowest total was 5 . Academic practice scores were based upon two statements and carried a high score of 10 and low score of 2 .

There were two trials were run in this study, where the identically designed surveys were used (detailed above). The first part of the study took place during the 2014-2015 school year, and the second part of the study was done in the 2015-2016 school year. In trial one, 40 surveys were administered fully by the lead researcher, the remaining nineteen were all directed for the first 5 minutes of administration by the lead researcher, but were collected and returned by other teachers who were made fully aware of the expectations. All surveys in trial two were administered fully by the two lead researchers. A sample survey was reviewed prior to their usage by a statistics professional (Dr. Sage Rose, Professor of Statistical Research at Hofstra University) during a specified meeting time to ensure that each question was linked properly to each assigned category. 


\section{Results}

\subsection{Trial One (2014-2015 School Year) Results}

Table 1. Correlation of gender and school enjoyment

\begin{tabular}{lccc}
\hline & & Gender & Enjoyment \\
\hline Gender & Sig (2-tailed) & 1 & $.411^{* *}$ \\
& $\mathrm{~N}$ & 59 & .001 \\
& & $.411^{* *}$ & 59 \\
Enjoyment & $\mathrm{Sig}(2$-tailed) & .001 & 1 \\
& $\mathrm{~N}$ & 59 & 59 \\
\hline
\end{tabular}

There was a significant relationship between gender and school enjoyment, $r=.41, \mathrm{p}<.05$.

Table 2. Trial 1 multivariate tests for level and/or gender

\begin{tabular}{|c|c|c|c|c|c|c|}
\hline Effect & & Value & $\mathrm{F}$ & Hypothesis df & Error df & Sig. \\
\hline \multirow[t]{4}{*}{ Intercept } & Pillai's Trace & .985 & $1041.711 b$ & 3.000 & 49.000 & .000 \\
\hline & Wilks' Lambda & .015 & $1041.711 b$ & 3.000 & 49.000 & .000 \\
\hline & Hotelling's Trace & 63.778 & $1041.711 b$ & 3.000 & 49.000 & .000 \\
\hline & Roy's Largest Root & 63.778 & $1041.711 b$ & 3.000 & 49.000 & .000 \\
\hline \multirow[t]{4}{*}{ Level } & Pillai’s Trace & .194 & 1.173 & 9.000 & 153.000 & .316 \\
\hline & Wilks' Lambda & .813 & 1.177 & 9.000 & 119.404 & .316 \\
\hline & Hotelling's Trace & .221 & 1.172 & 9.000 & 143.000 & .317 \\
\hline & Roy's Largest Root & .173 & $2.944 \mathrm{c}$ & 9.000 & 51.000 & .042 \\
\hline \multirow[t]{4}{*}{ Gender } & Pillai’s Trace & .176 & $3.491 \mathrm{~b}$ & 3.000 & 49.000 & .022 \\
\hline & Wilks' Lambda & .824 & $3.491 \mathrm{~b}$ & 3.000 & 49.000 & .022 \\
\hline & Hotelling's Trace & .214 & $3.491 \mathrm{~b}$ & 3.000 & 49.000 & .022 \\
\hline & Roy's Largest Root & .214 & $3.491 \mathrm{~b}$ & 3.000 & 49.000 & .022 \\
\hline \multirow[t]{4}{*}{ Level * Gender } & Pillai's Trace & .099 & .578 & 9.000 & 153.000 & .814 \\
\hline & Wilks' Lambda & .904 & .561 & 9.000 & 119.404 & .827 \\
\hline & Hotelling's Trace & .103 & .545 & 9.000 & 143.000 & .840 \\
\hline & Roy's Largest Root & .053 & $.900 \mathrm{c}$ & 3.000 & 51.000 & .448 \\
\hline
\end{tabular}

\footnotetext{
a. Design: Intercept+Level+Gender+Level*Gender.

b. Exact statistic.

c. The statistic is an upper bound on $\mathrm{F}$ that yields a lower bound on the significance level.

Our Wilks Lambda is significant for gender $F(3,49)$, $p<.05$.
}

The opening trial of the study showed significance related to gender and enjoyment. There was a significant main effect of gender on enjoyment, as initially noted by the MANOVA that was done. Significance was shown for the Wilks' Lambda $\mathrm{F}(3,49), \mathrm{p}<.05$ on Table 2 as well as for Table 3 analyzing between-subject variances, $\mathrm{F}(1,51)=$ $8.66, \mathrm{p}<.05$. A follow-up t-test was done, due to the lower than ideal number of MANOVA subjects (59 students). During this t-test, it became evident that girls have a higher mean enjoyment level (11.81) than boys (8.97) as shown by Table 4 and Table 5. There was statistical significance at the .05 level when the t-test results were run. 
The possible reasons for the Levene's results are discussed and explained in the "Limitations" section. Due to these results, the "Equal variances not assumed" correction category was used.

Table 3. Trial 1 test of between subjects effects for level and/or gender on perception, enjoyment, and/or practice

\begin{tabular}{|c|c|c|c|c|c|c|}
\hline Source & Dependent Variable & $\begin{array}{l}\text { Type III Sum of } \\
\text { Squares }\end{array}$ & df & Mean Square & $\mathrm{F}$ & Sig \\
\hline \multirow[t]{3}{*}{ Corrected Model } & Perception & $23.399 \mathrm{a}$ & 7 & 3.343 & .750 & .631 \\
\hline & Enjoyment & $141.799 b$ & 7 & 20.257 & 1.845 & .099 \\
\hline & Practice & $44.504 \mathrm{c}$ & 7 & 6.358 & 1.003 & .440 \\
\hline \multirow[t]{3}{*}{ Intercept } & Perception & 13696.788 & 1 & 13696.788 & 3073.017 & .000 \\
\hline & Enjoyment & 4483.516 & 1 & 4483.516 & 408.421 & .000 \\
\hline & Practice & 2033.491 & 1 & 2033.491 & 320.855 & .000 \\
\hline \multirow[t]{3}{*}{ Level } & Perception & 7.123 & 3 & 2.374 & .533 & .662 \\
\hline & Enjoyment & 11.888 & 3 & 3.963 & .361 & .781 \\
\hline & Practice & 22.556 & 3 & 7.519 & 1.186 & .324 \\
\hline \multirow[t]{3}{*}{ Gender } & Perception & .002 & 1 & .002 & .000 & .982 \\
\hline & Enjoyment & 95.082 & 1 & 95.082 & 8.661 & .005 \\
\hline & Practice & 4.236 & 1 & 4.236 & .668 & .417 \\
\hline \multirow[t]{3}{*}{ Level*Gender } & Perception & 7.736 & 3 & 2.579 & .579 & .632 \\
\hline & Enjoyment & 10.213 & 3 & 3.404 & .310 & .818 \\
\hline & Practice & 7.615 & 3 & 2.538 & .400 & .753 \\
\hline \multirow[t]{3}{*}{ Error } & Perception & 227.313 & 51 & 4.457 & & \\
\hline & Enjoyment & 559.862 & 51 & 10.978 & & \\
\hline & Practice & 323.224 & 51 & 6.338 & & \\
\hline \multirow[t]{3}{*}{ Total } & Perception & 20388.000 & 59 & & & \\
\hline & Enjoyment & 6926.000 & 59 & & & \\
\hline & Practice & 3315.000 & 59 & & & \\
\hline \multirow[t]{3}{*}{ Corrected Total } & Perception & 250.712 & 58 & & & \\
\hline & Enjoyment & 701.661 & 58 & & & \\
\hline & Practice & 367.729 & 58 & & & \\
\hline
\end{tabular}

\footnotetext{
a. $\mathrm{R}$ Squared $=.093$ (Adjusted R Squared=-.031).

b. R Squared $=.202$ (Adjusted R Squared=.093).

c. R Squared=.121 (Adjusted R Squared=.000).
}

A MANOVA was performed and a significant main effect was found for gender on enjoyment, $F(1,51)=8.66, \mathrm{p}<.05$. 
Table 4. Trial 1 group statistics for gender on enjoyment

\begin{tabular}{cccccc}
\hline & Gender & $\mathrm{N}$ & Mean & Std. Deviation & Std. Error Mean \\
\hline \multirow{3}{*}{ Perception } & Boy & 32 & 8.9688 & 3.81410 & .67424 \\
& Girl & 27 & 11.8148 & 2.25383 & .43375
\end{tabular}

All of this information was preceded by data from a bivariate correlation, as seen on Table 1. While this was run for all available relationships, only gender and enjoyment demonstrated a significant correlation, although the level of this correlation could not be termed "strong" $(\mathrm{r}=.41, \mathrm{p}<.05)$. This would signify an $\mathrm{r}$ score that is on the more moderate side in regards to correlation. There were no other variables or interaction effects that were significant at the $\mathrm{p}<.05$ level for any trial one model done to test the research questions. As stated earlier, gender and enjoyment were the only two areas that displayed significance in the multiple analyses that were run. Tests that did not show significance will not be included. Formal APA-guided statements accompany all available charts to add clarity to the research.

Table 5. Trial $1 \mathrm{t}$-test for gender and enjoyment

\begin{tabular}{|c|c|c|c|c|c|c|c|c|c|c|}
\hline & & \multicolumn{3}{|c|}{$\begin{array}{c}\text { Levene's Test for } \\
\text { Equality of Variances }\end{array}$} & - & \multicolumn{2}{|c|}{$\begin{array}{l}\text { t-test for Equality of } \\
\text { Means }\end{array}$} & & & \\
\hline \multirow{4}{*}{ Enjoyment } & & & & & & Sig. (2- & Mean & Std. Error & $95 \%$ Confidence Interva & of the difference \\
\hline & & $\mathrm{F}$ & Sig. & $\mathrm{t}$ & $\mathrm{df}$ & tailed) & Difference & Difference & Lower & Upper \\
\hline & assumed & & & & & & & & & \\
\hline & $\begin{array}{l}\text { Equal } \\
\text { variances not } \\
\text { assumed }\end{array}$ & & & -3.550 & 51.460 & .001 & -2.84606 & .80171 & -4.45522 & -1.23691 \\
\hline
\end{tabular}

Levene's Test for Equality of Variances has found unequal variances $F(14.27, .00)$. Due to the Levene's Test results, our data from the "Equal variances not assumed" category must be used. There was a significant difference between boys $(8.97,3.81)$ and girls $(11.81,2.25)$ on enjoyment score.

Table 6. Trial 1 multivariate tests for level and/or gender

\begin{tabular}{crrrrrr}
\hline Effect & & Value & \multicolumn{1}{c}{ F } & Hypothesis df & Error df & Sig. \\
\hline Intercept & Pillai's Trace & .979 & $1415.557 \mathrm{~b}$ & 3.000 & 93.000 & .000 \\
& Wilks' Lambda & .021 & $1415.557 \mathrm{~b}$ & 3.000 & 93.000 & .000 \\
& Hotelling's Trace & 45.663 & $1415.557 \mathrm{~b}$ & 3.000 & 93.000 & .000 \\
& Roy's Largest Root & 45.663 & $1415.557 \mathrm{~b}$ & 3.000 & 93.000 & .000 \\
Gender & Pillai's Trace & .168 & $6.274 \mathrm{~b}$ & 3.000 & 93.000 & .001 \\
& Wilks' Lambda & .832 & $6.274 \mathrm{~b}$ & 3.000 & 93.000 & .001 \\
& Hotelling's Trace & .202 & $6.274 \mathrm{~b}$ & 3.000 & 93.000 & .001 \\
& Roy's Largest Root & .202 & $6.274 \mathrm{~b}$ & 3.000 & 93.000 & .001 \\
Level & Pillai's Trace & .114 & 1.247 & 9.000 & 285.000 & .266 \\
& Wilks' Lambda & .889 & 1.247 & 9.000 & 226.488 & .267 \\
\hline
\end{tabular}




\begin{tabular}{rrrrrrr}
\hline & Hotelling's Trace & .122 & 1.247 & 9.000 & 275.000 & .269 \\
Roy's Largest Root & .091 & $2.880 \mathrm{c}$ & 3.000 & 95.000 & .040 \\
Level * Gender & Pillai's Trace & .021 & .224 & 9.000 & 285.000 & .991 \\
& Wilks' Lambda & .979 & .221 & 9.000 & 226.488 & .991 \\
& Hotelling's Trace & .021 & .218 & 9.000 & 275.000 & .992 \\
& Roy's Largest Root & .018 & $.573 \mathrm{c}$ & 3.000 & 95.000 & .634 \\
\hline
\end{tabular}

a. Design: Intercept+Gender+Level+Gender*Level.

b. Exact statistic.

c. The statistic is an upper bound on $\mathrm{F}$ that yields a lower bound on the significance level.

Our Wilks Lambda is significant for gender $F(3,93)$, $p<.05$.

Table 7. Trial 2 test of between subjects effects for level and/or gender on perception, enjoyment, and/or practice

\begin{tabular}{|c|c|c|c|c|c|c|}
\hline Source & Dependent Variable & Type III Sum of Squares & $\mathrm{df}$ & Mean Square & $\mathrm{F}$ & Sig. \\
\hline \multirow[t]{3}{*}{ Corrected Model } & Perception & $153.378 \mathrm{a}$ & 7 & 21.911 & 2.858 & .009 \\
\hline & Enjoyment & $128.509 b$ & 7 & 18.358 & 3.154 & .005 \\
\hline & Practice & $59.698 \mathrm{c}$ & 7 & 8.528 & 2.703 & .013 \\
\hline \multirow[t]{3}{*}{ Intercept } & Perception & 27660.704 & 1 & 27660.704 & 3607.356 & .000 \\
\hline & Enjoyment & 10445.438 & 1 & 10445.438 & 1794.408 & .000 \\
\hline & Practice & 3740.268 & 1 & 3740.268 & 1185.375 & .000 \\
\hline \multirow[t]{3}{*}{ Gender } & Perception & 34.741 & 1 & 34.741 & 4.531 & .036 \\
\hline & Enjoyment & 70.549 & 1 & 70.549 & 12.120 & .001 \\
\hline & Practice & 44.055 & 1 & 44.055 & 13.962 & .000 \\
\hline \multirow[t]{3}{*}{ Level } & Perception & 60.818 & 3 & 20.273 & 2.644 & .054 \\
\hline & Enjoyment & 12.370 & 3 & 4.123 & .708 & .549 \\
\hline & Practice & 5.285 & 3 & 1.762 & .558 & .644 \\
\hline \multirow[t]{3}{*}{ Gender*Level } & Perception & 2.477 & 3 & .826 & .108 & .955 \\
\hline & Enjoyment & 1.667 & 3 & .556 & .095 & .962 \\
\hline & Practice & 5.351 & 3 & 1.784 & .565 & .639 \\
\hline \multirow[t]{3}{*}{ Error } & Perception & 728.447 & 95 & 7.668 & & \\
\hline & Enjoyment & 553.005 & 95 & 5.821 & & \\
\hline & Practice & 299.758 & 95 & 3.155 & & \\
\hline \multirow[t]{3}{*}{ Total } & Perception & 41643.000 & 103 & & & \\
\hline & Enjoyment & 15900.000 & 103 & & & \\
\hline & Practice & 6071.000 & 103 & & & \\
\hline Corrected Total & Perception & 881.825 & 102 & & & \\
\hline
\end{tabular}




\begin{tabular}{lll}
\hline Enjoyment & 681.515 & 102 \\
Practice & 359.456 & 102 \\
\hline
\end{tabular}

a. $\mathrm{R}$ Squared=.174 (Adjusted R Squared=.113).

b. $\mathrm{R}$ Squared=.189 (Adjusted R Squared=.129).

c. R Squared=.166 (Adjusted R Squared=.105).

A MANOVA was performed and a significant main effect was found for gender on perception, $\mathrm{F}(1,95)=4.53$; enjoyment, $\mathrm{F}(1,95)=12.12$; and academic practice $\mathrm{F}(1,95)=13.96, \mathrm{p}<.05$.

This portion of the study also demonstrated that gender is linked to enjoyment. In the study of the MANOVA (Tables $6 \& 7$ ) there was a significant main effect of gender on enjoyment. The Wilks Lambda indicated that gender was something that should be studied further. Our Wilks Lambda is significant for gender $F(3,93), p<.05$. In Table 7 further connections between gender and enjoyment were shown. However, unlike trial one of this study, gender demonstrated significance in other areas of this statistical representation. A MANOVA was performed and a significant main effect was found for gender on perception, $\mathrm{F}(1,95)=4.53$; enjoyment $\mathrm{F}(1,95)=12.12$; academic practice $\mathrm{F}(1,95)=13.96, \mathrm{p}<.05$. The impact of gender on the areas of self-perception and academic practice are seen for the first time here. They have emerged as a clear difference between the data collected from these two trials. There was a similarity that appeared to show itself during Levene's Test, which aims to provide sample analysis, came up as significant. Though this is typically undesirable, further testing would shed new light on the validity of this basic overview.

Table 8. Trial 2 group statistics for gender on perception

\begin{tabular}{cccccc}
\hline & Gender & $\mathrm{N}$ & Mean & Std. Deviation & Std. Error Mean \\
\hline \multirow{3}{*}{ Perception } & Boy & 49 & 18.9388 & 2.91839 & .41691 \\
& Girl & 54 & 20.7593 & 2.70524 & .36814 \\
\hline
\end{tabular}

Table 9. Trial 2 independent samples t-test for gender on perception

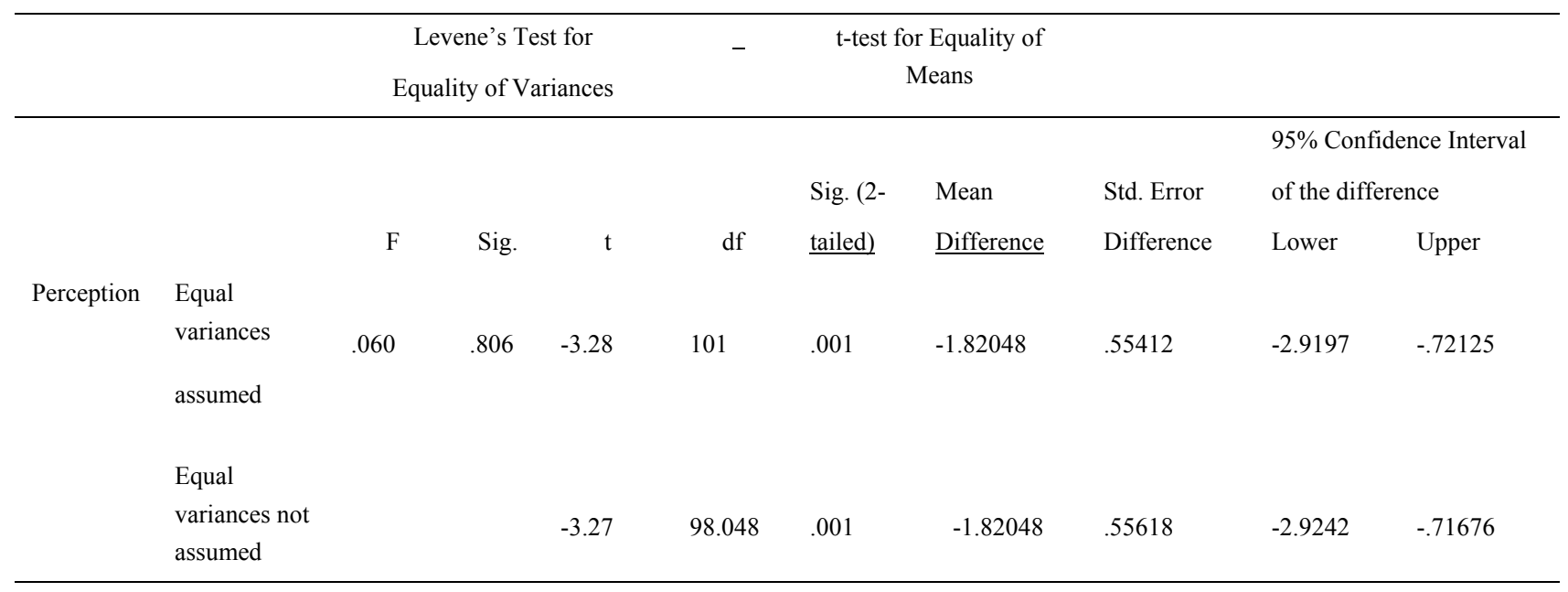

There was a significant difference between boys $(18.94,2.92)$ and girls $(20.76,2.71), \mathrm{p}<.05$ on perception score. 
Table 10. Trial 2 group statistics for gender on academic practice

\begin{tabular}{cccccc}
\hline & Gender & $\mathrm{N}$ & Mean & Std. Deviation & Std. Error Mean \\
\hline \multirow{2}{*}{ Practice } & Boy & 49 & 6.7143 & 2.00000 & .28571 \\
& Girl & 54 & 8.1111 & 1.48790 & .20248 \\
\hline
\end{tabular}

More specific tests were done as a result of the overview provided by the MANOVA. Table 9, an independent sample t-test showed there was a significant difference between boys $(18.94,2.92)$ and girls $(20.76,2.71)$ on perception score, as also shown in Table 8 . The research was furthered by two more t-test results. Table 11 is critical when reviewing the sample in more detail. There was a significant difference between boys $(6.71,2)$ and girls $(8.11,1.49), \mathrm{p}<.05$ academic practice score. Although initial MANOVA results intimated that there were possible concerns about the diversity of the sample, further, more specific, review from this t-test removed the potential for this possible issue. Much like the first trial of this study, Table 13 reveals similar significance to Table 5. There was a significant difference between boys $(11.1,2.6)$ and girls $(13.13,2.21), \mathrm{p}<.05$ on enjoyment scores. Thus, there is a reconfirmation of the links found in the MANOVA regarding the fixed factor of gender and the three dependent variables tested. The difference between the mean scores favored girls at all junctures. Boys indicated significantly lower scores in the areas of perception, academic practice, and enjoyment than that of their female counterparts. There was an obvious difference between the two genders on these tests.

Table 11. Trial 2 independent samples test for gender on academic practice

\begin{tabular}{|c|c|c|c|c|c|c|c|c|c|c|}
\hline & & \multicolumn{3}{|c|}{$\begin{array}{c}\text { Levene's Test for } \\
\text { Equality of Variances }\end{array}$} & \multirow[t]{2}{*}{-} & \multicolumn{2}{|c|}{$\begin{array}{l}\text { t-test for Equality of } \\
\text { Means }\end{array}$} & & \multicolumn{2}{|c|}{$95 \%$ Confidence Interva } \\
\hline & & \multirow[b]{2}{*}{$\mathrm{F}$} & \multirow[b]{2}{*}{ Sig. } & \multirow[b]{2}{*}{$\mathrm{t}$} & & \multirow{2}{*}{$\begin{array}{l}\text { Sig. (2- } \\
\text { tailed) }\end{array}$} & \multirow{2}{*}{$\begin{array}{l}\text { Mean } \\
\text { Difference }\end{array}$} & \multirow{2}{*}{$\begin{array}{l}\text { Std. Error } \\
\text { Difference }\end{array}$} & \multicolumn{2}{|c|}{ of the difference } \\
\hline & & & & & df & & & & Lower & Upper \\
\hline \multirow[t]{3}{*}{ Practice } & $\begin{array}{l}\text { Equal } \\
\text { variances }\end{array}$ & 3.722 & .056 & -4.04 & 101 & .000 & -1.39683 & .34528 & -2.0817 & -.71187 \\
\hline & assumed & & & & & & & & & \\
\hline & $\begin{array}{l}\text { Equal } \\
\text { variances not } \\
\text { assumed }\end{array}$ & & & -3.98 & 88.177 & .000 & -1.39683 & .35019 & -2.0927 & -.70093 \\
\hline
\end{tabular}

There was a significant difference between boys $(6.71,2)$ and girls $(8.11,1.49), \mathrm{p}<.05$ on academic practice score. Initial MANOVA results intimated that homogeneity was a concern, further review via t-test has removed the potential for this occurrence.

Table 12. Trial 2 group statistics for gender on enjoyment

\begin{tabular}{cccccc}
\hline & Gender & $\mathrm{N}$ & Mean & Std. Deviation & Std. Error Mean \\
\hline \multirow{2}{*}{ Enjoyment } & Boy & 49 & 11.0816 & 2.56447 & .36635 \\
& Girl & 54 & 13.1296 & 2.20673 & .30030 \\
\hline
\end{tabular}


Table 13. Independent samples t-test for gender on enjoyment

\begin{tabular}{|c|c|c|c|c|c|c|c|c|c|c|}
\hline & & \multicolumn{3}{|c|}{$\begin{array}{l}\text { Levene's Test for } \\
\text { Equality of Variances }\end{array}$} & \multirow[t]{2}{*}{ - } & \multicolumn{2}{|c|}{$\begin{array}{l}\text { t-test for Equality of } \\
\text { Means }\end{array}$} & & \multirow{2}{*}{\multicolumn{2}{|c|}{$95 \%$ Confidence Interval }} \\
\hline & & \multirow[b]{2}{*}{$\mathrm{F}$} & \multirow[b]{2}{*}{ Sig. } & \multirow[b]{2}{*}{$\mathrm{t}$} & & \multirow{2}{*}{$\begin{array}{l}\text { Sig. }(2- \\
\text { tailed) }\end{array}$} & \multirow{2}{*}{$\begin{array}{l}\text { Mean } \\
\text { Difference }\end{array}$} & \multirow{2}{*}{$\begin{array}{l}\text { Std. Error } \\
\text { Difference }\end{array}$} & & \\
\hline & & & & & $\mathrm{df}$ & & & & Lower & Upper \\
\hline \multirow[t]{3}{*}{ Enjoyment } & $\begin{array}{l}\text { Equal } \\
\text { variances }\end{array}$ & 2.095 & .151 & -4.35 & 101 & .000 & -2.04800 & .47025 & -2.9808 & -1.11514 \\
\hline & assumed & & & & & & & & & \\
\hline & $\begin{array}{l}\text { Equal } \\
\text { variances not } \\
\text { assumed }\end{array}$ & & & -4.32 & 95.234 & .000 & -2.04800 & .47370 & -2.9883 & -1.10761 \\
\hline
\end{tabular}

There was a significant difference between boys $(11.1,2.6)$ and girls $(13.13,2.21), \mathrm{p}<.05$ on enjoyment score.

Further testing was done to assist in creating a more holistic picture of the survey data. In Tables 14-16 (a collection of correlation studies) a significant relationship was shown between gender and self-perception, $\mathrm{r}=.31$; academic practice, $\mathrm{r}=.37$; and enjoyment, $\mathrm{r}=.39, \mathrm{p}<.05$. This is a very respectable level of correlation in the world of statistics. The data is indicated that in all cases gender plays a significant role in many vital areas of a given learner. Gender differences were consistent throughout all tested areas for this portion of the study.

Table 14. Trial 2 correlation of gender and perception

\begin{tabular}{llcc}
\hline & & Gender & Perception \\
\hline Gender & Pearson Correlation & 1 & $.311^{* *}$ \\
& Sig. (2-tailed) & & .001 \\
& $\mathrm{~N}$ & 103 & 103 \\
Perception & Pearson Correlation & $.311^{* *}$ & 1 \\
& Sig. (2-tailed) & .001 & \\
& $\mathrm{~N}$ & 103 & 103 \\
\hline
\end{tabular}

**. Correlation is significant at the 0.01 level (2-tailed).

There was a significant relationship between gender and perception, $\mathrm{r}=.31, \mathrm{p}<.05$.

Table 15. Trial 2 correlation of gender and academic practice

\begin{tabular}{llrr}
\hline & & Gender & Practice \\
\hline Gender & Pearson Correlation & 1 & $.373^{* *}$ \\
& Sig. (2-tailed) & & .000 \\
& $\mathrm{~N}$ & 103 & 103 \\
Practice & Pearson Correlation & $.373^{* *}$ & 1 \\
& Sig. (2-tailed) & .000 & \\
& $\mathrm{~N}$ & 103 & 103 \\
\hline
\end{tabular}

\footnotetext{
**. Correlation is significant at the 0.01 level (2-tailed).
} 
There was a significant relationship between gender and academic practice, $\mathrm{r}=.37, \mathrm{p}<.05$.

Table 16. Trial 2 correlation of gender and enjoyment

\begin{tabular}{llrr}
\hline & & Gender & \multicolumn{2}{c}{ Enjoyment } \\
\hline Gender & Pearson Correlation & 1 & $.398^{* *}$ \\
& Sig. (2-tailed) & & .000 \\
& $\mathrm{~N}$ & 103 & 103 \\
Enjoyment & Pearson Correlation & $.398^{* *}$ & 1 \\
& Sig. (2-tailed) & .000 & \\
& $\mathrm{~N}$ & 103 & 103 \\
\hline
\end{tabular}

**. Correlation is significant at the 0.01 level (2-tailed).

There was a significant relationship between gender and perception, $\mathrm{r}=.39, \mathrm{p}<.05$.

\section{Interpretation of the Data}

The two trials performed in this study uncovered some commonalities, yet diverged with regards to the actual depth of the impact of gender. Trial one noted significance in the singular area of gender on school enjoyment. While, on the other hand, more of the data collected from trial two turned out to be statistically significant with regards to the tests performed. There was a repetitive theme placing gender as a possible determining factor in the aforementioned area of school enjoyment, academic practice, and self-perception. Gender presented itself in a significant fashion for each test represented in trial two. The trials concurred in their ranking of girls' superior level of school enjoyment. The similarities and differences could be due to a variety of circumstances, or even a confluence of some circumstances together. They must be considered in light of the results found.

A manner of great importance is the age and demographics of the students and faculty. In this district, students first attend a K-1 center and then attend the school that the study was conducted in, a mostly-intermediate school for grades 2-5. In the K-1 center there are currently no male classroom teachers. In the school utilized for this study, there are no male instructors in grades two or three, and only three male instructors for grades four and five. The elevated enjoyment scores for girls might play somewhat into this school faculty make-up. That is not to suggest that a female teacher cannot support male students just as well as male teachers, but in this school system, it is rather evident that male role models are lacking for young boys. One has to postulate how this survey might play out for eighth grade students who have exposure to a more equally divided staff in regards to gender.

Self-perception and academic practice were also an area of interest from trial two. Females might have seen themselves in a more positive light due to the community of learners that surround them. It is not difficult to see oneself as a positive member of the literacy world when the prevalent school environment offers an array of successful adult females to model oneself after. In sheer peer numbers alone, girls slightly outnumber boys in trial two, which is representative of the school at large. Even if a teacher is seeking to simply appeal to the masses, the choice might be slightly skewed towards female interest bases due to this numerical inequality. When a connection to the material does not exist, perhaps males might be left with more negative views of themselves, and the process of reading and writing as a whole. This speaks directly to academic practice as well. The information from the "Literature Review" section seeks to link the idea that those who have a higher level of self-confidence are more likely to engage in literacy events on a regular basis. Affective motivations connect to views of reading and writing as viable leisure time activities for boys.

It was surprising that reading level was not found to be significant at any juncture in either of the trials run in this study. This could present the idea that students of the elementary age may not have a large-scale awareness of their reading level when compared to others. These students are still young and they do not let it impact their self-perception in a significant way, nor does it seem to affect their enjoyment of school. The academic stressors that high school students feel, such as pressures to keep high grades in order to be accepted into college do not exist in this environment. Scholarship money and sports team participation requirements are also not items of concern for the elementary-level learners. Additionally, it is not surprising that the higher level students did not show higher practice scores than their lower level counterparts as some might expect. Students who are lower readers are often prompted to practice more frequently by their teachers than those who are not at-risk, though some will and 
some won't. There are many scenarios where tutors are hired for these struggling readers to allow for more reading and writing practice. This is then mixed with higher level students who might show similar scores because they simply enjoy reading as a leisure activity. Significant differences are not likely to be found when these circumstances are fully considered.

Further, in modern schools the "average student" as noted by the level 3 (on the scale of 1-4 for student reading level) students in our survey often don't find a special designation. The top level students (level 4 in our survey) are considered gifted. Level 1 and 2 students are given special services such as Academic Intervention Services and Resource Room. This lack of additional recognition for level 3 students could have a pervasive effect on many aspects of being a student at the elementary level. It is sometimes referred to as slipping through the proverbial cracks of the educational system.

The study has shed light upon the idea that girls and boys potentially have rather different views on the school experience. Much of the study data was supported by extensive research from those cited in the "Literature Review" section of this paper. Teachers must strive daily to ensure that they are reaching not just some of those in their class, but attempt to reach everyone in their class. An egalitarian environment that draws upon influences and points of interest from a diverse array or sources will appeal more readily to those who might be otherwise lost.

\section{Limitations}

\subsection{Trial One (2014-2015 School Year) Limitations}

There were limitations in some areas of this study. The amount of students that the researcher was allowed to test was limited to 59 students ( 3 classes). This was not a choice, but rather a circumstance of the amount of students that could be seen by the researcher over the course of an average day. Though this gave a somewhat close number of girls and boys, the number of students in the highest reading level was a bit low ( 8 students). This is a total student number (59) that is viewed as less than ideal for running a MANOVA. Other tests had to be employed to further verify or support any findings. Also, the teachers remained in the room during the completion of the surveys which could have an influence on the responses that the students put down. This was unavoidable, as certified teachers must be supervising the students at all times. Under more ideal circumstances, one would have wanted more participants, and perhaps used more grades than simply grade five. "Grade level" could have been an additional independent variable that would have been interesting to add to this study.

\subsection{Trial Two (2015-2016 School Year) Limitations}

This was a much more comprehensive portion of the study, as it compiled data from a larger number of students. This numerical rise is typically viewed as a positive item, but obtaining more students led to possible issues with the way the data had to be gathered. Students were either pulled from their rooms or had their rooms temporarily overtaken by the two lead researchers, of whom they may or may not have known. This might have caused some possible added stress for the students as they completed each survey.

The wider age range of the students is another seemingly improved aspect of trial two of this study. Yet, the tendencies for students in the lower grades might not be aimed towards providing fully honest results, and could potentially be viewed as an act to write down responses that would bring approbation from their respective teachers or parental figures. Though the students were vehemently reassured that the surveys would not be used for anything related to grades or home contact, there is nothing that can entirely counteract the compliant mentality of some younger children.

\subsection{General Limitations}

Another limiting factor came up during a review of Levene's Test for Homogeneity. It appears that the "in-group variation" was a potential problem for each gender. Levene's came up as significant during the t-test used in trial one to further tease out the results found on the MANOVA. It is notable that a t-test vindicated the sample conversely in trial two. It appears to find mild significance at best in both trials in the instances that it did occur. After going through the survey on an individual level, the reasons for this became clearer. The surveys were comprised of a series of questions that each would be rated out of five, then a raw score would be created from adding these scores together in each area of the study. Enjoyment raw scores were very similar for both genders. However, the answers to each individual question did show variation. While particular question answers varied, the raw scores could remain close as some students would give higher ratings in different areas and also low in certain areas. For example, a student could rate writing enjoyment at 1 but reading enjoyment at a 5. The alternative scenario ( 5 for writing, 1 for reading) still yields a net total of 6 quality points. These were not the only questions geared towards judging enjoyment, but the point is clear; different answers were arriving at the same place in regards to raw scoring. 


\section{Implications}

This study has an array of both research and educational implications. The reasoning behind pursuing two separate trials was to see how the data would play out with larger and smaller samples. The dual trials also generated more favorable conditions for the data analysis tests that were run, and highlighted any themes that appeared strongly in both of these trials. These goals appear to have been achieved in regards to the way in which the results were obtained.

The area that appears to be most prominent, due to its significance in both studies, was the effect of gender on school enjoyment. This is certainly an area of study that will lend itself readily to further research. In both studies, the correlations came back with extremely close numbers. Trial one led to an $r$ score of .41 and trial two resulted in an $r$ score of .39. These correlation scores are stronger than any other correlations noted for any other variable in either trial. In both trials, female students had higher levels of school enjoyment than males. Since this is the single area of variable data that is confirmed by both trials, the urgency behind ascertaining potential reasons or explanations behind it are thereby heightened in their importance levels.

While it is evident that the way gender affects school enjoyment is a topic of interest, gender's impact upon self-perception and academic practice must not be discounted. Again, females possessed higher mean scores in both areas. These were factors that arose as a result of assessing the larger, more inclusive sample size in trial two. Further research related to both relationships (gender on self-perception, gender on academic practice) will be needed. It appears that of these two, researching the effect of gender on academic practice would be of a slightly higher priority, as there was correlation with an $\mathrm{r}$ score of .37, as well as relatively higher gap between mean scores of females and males. Self-perception results demonstrated an $\mathrm{r}$ score of .31 , showing a somewhat lower correlation than that of academic practice, and relative mean difference between genders that is smaller than that of the academic practice scores. These relational differences are demonstrated in Figures 1-3.

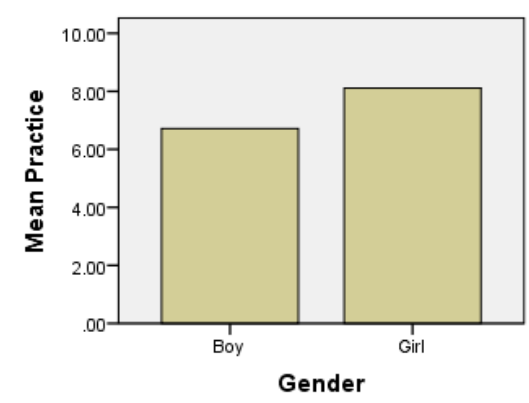

Figure 1. Trial 2 practice means by gender

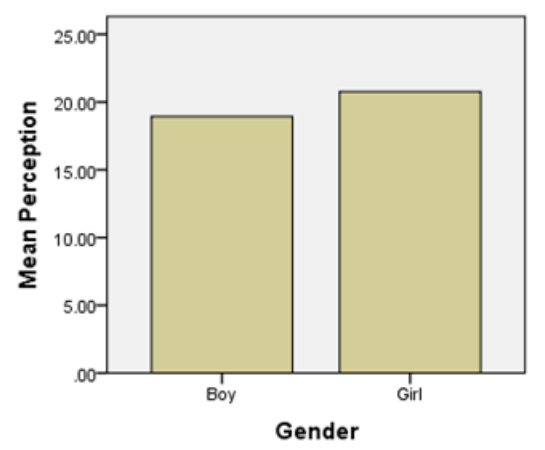

Figure 2. Trial 2 enjoyment means by gender 


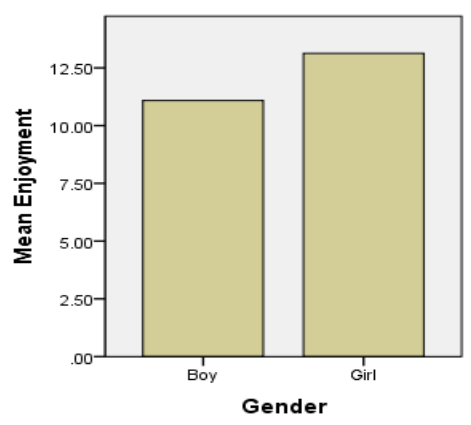

Figure 3. Trial 2 perception means by gender

The path forward can go in a variety of directions. Additional quantitative work that focuses upon more detailed aspects of each significant independent variable in the study is worthy of pursuit. Also, there is nothing ruling out the idea of qualitative methods being utilized to begin to look at this data from an entirely different perspective. This study has shown "the what", and to some the degree, "the how", in relation to the aspects of students that their respective genders may influence. Would a study that seeks to look into "the why" be the logical next step? As educators move forward with the knowledge of the results of this study, more information will come to the forefront that can better fill in the pieces of this puzzle and perhaps move towards a greater level of understanding of the students that they teach.

\section{References}

Bausch, L. (2014). Boys Will Be Boys? Bridging the Great Gendered Literacy Divide. Rotterdam, Netherlands: Sense Publishers. https://doi.org/10.1007/978-94-6209-539-7

Chiu, M., \& McBride-Chang, C. (2006). Gender, Context, and Reading: A comparison of students in 43 countries. China University of Hong Kong. https://doi.org/10.1207/s1532799xssr1004_1

Coombs, D., \& Edwards, N. (2013). Making reading accessible for struggling readers. Utah Journal of Literacy, 16(1), 23-29.

Duckworth, A. L., \& Seligman, M. E. (2006). Self-discipline gives girls the edge: Gender in self-discipline, grades, and achievement test scores. Journal of Educational Psychology, 98(1), 198. https://doi.org/10.1037/0022-0663.98.1.198

Goodman, Y., \& Goodman, K. (2003). To err is human: Learning about language processes by analyzing miscues. In A. Flurkey, \& J. Xu (Eds.), Revolution in reading: The selected writings of Kenneth S. Goodman on the reading process. Portsmouth, $\mathrm{NH}$ : Heinemann.

Kifer, E. (1973, February). The effects of school achievement on the affective traits of the learner. Annual meeting of the American educational research association.

Gentry, M., Gable, R., \& Rizza, M. (2002). Students perceptions of classroom activities: Are there grade-level and gender differences. Journal of Educational Psychology, 93(3), 539-544. https://doi.org/10.1037/0022-0663.94.3.539

Pajares, F. (2003). Self-Efficacy beliefs, motivation and achievement in writing: A review of literature. Reading \& Writing Quarterly, 19(1), 139-158. https://doi.org/10.1080/10573560308222

Pajares, F., \& Johnson, M. (1993). Confidence and competence in writing: The role of self-efficacy, outcome expectancy, and apprehension. Annual Meeting of the American Educational Research Association.

Santarpia, S., \& Voos, K. (2003). Reading Anxiety. LRP Publications, 1(2), 3-32.

Schirmer, B. R., \& Schaffer, L. (2010). Guided Reading Approach: A Lesson Structure for Teaching Reading to Students Who are Deaf and Others Who Struggle. Teaching Exceptional Children, 42(5), 52-58. https://doi.org/10.1177/004005991004200506

Smithsonian Institution. (June 25, 2015). One species, living worldwide. Retrieved from http://humanorigins.si.edu/evidence/genetics/one-species-living-worldwidehttp://humanorigins.si.edu/evide nce/genetics/one-species-living-worldwide 
Yopp, R., \& Dreher, M. (1994). Effects of active comprehension instruction on attitudes and motivation in reading. Reading Horizons, 34(4), 289-302.

\section{Appendix}

Sample Student Survey

\begin{tabular}{|c|c|c|c|c|c|c|}
\hline & $\begin{array}{l}\text { Far Below } \\
\text { Average }\end{array}$ & $\begin{array}{l}\text { Somewhat } \\
\text { Average }\end{array}$ & Below & Average & $\begin{array}{l}\text { Somewhat Above } \\
\text { Average }\end{array}$ & $\begin{array}{l}\text { Far Above } \\
\text { Average }\end{array}$ \\
\hline \multicolumn{7}{|c|}{ How do you view yourself as a reader? } \\
\hline \multicolumn{7}{|c|}{ How do you view yourself as a writer? } \\
\hline \multirow{2}{*}{\multicolumn{7}{|c|}{$\begin{array}{l}\text { How do you view yourself as an overall } \\
\text { learner? }\end{array}$}} \\
\hline & & & & & & \\
\hline \multicolumn{7}{|l|}{ How do you rate your teachers? } \\
\hline & $\begin{array}{l}\text { Strongly } \\
\text { Disagree }\end{array}$ & Somewhat & isagree & $\begin{array}{l}\text { Neither Agree nor } \\
\text { Disagree }\end{array}$ & Somewhat Agree & Strongly Agree \\
\hline \multicolumn{7}{|l|}{ I enjoy reading. } \\
\hline \multicolumn{7}{|l|}{ I enjoy writing. } \\
\hline \multicolumn{7}{|l|}{ I enjoy going to school. } \\
\hline \multicolumn{7}{|c|}{ My teacher helps me when I need it. } \\
\hline Never & Rarely & & Unsure & Sometin & Alway & \\
\hline \multicolumn{7}{|l|}{ I read for pleasure. } \\
\hline I write for pleasure. & & & & & & \\
\hline
\end{tabular}

\section{Copyrights}

Copyright for this article is retained by the author(s), with first publication rights granted to the journal.

This is an open-access article distributed under the terms and conditions of the Creative Commons Attribution license (http://creativecommons.org/licenses/by/4.0/). 